This item was submitted to Loughborough's Research Repository by the author.

Items in Figshare are protected by copyright, with all rights reserved, unless otherwise indicated.

\title{
Mechatronics challenge for the higher education world
}

PLEASE CITE THE PUBLISHED VERSION

https://doi.org/10.1109/3476.585140

PUBLISHER

(c) IEEE

VERSION

AM (Accepted Manuscript)

LICENCE

CC BY-NC-ND 4.0

REPOSITORY RECORD

Acar, Memis. 2019. "Mechatronics Challenge for the Higher Education World". figshare.

https://hdl.handle.net/2134/27170. 


\title{
Mechatronics Challenge for the Higher Education World
}

\author{
Dr Memis ACAR, FIMechE, MASME \\ Department of Mechanical Engineering, Loughborough University, Loughborough, Leics, LE11 $3 T U$ \\ E-mail: M.Acar@lboro.ac.uk, Phone +44 1509 223218, Fax: +44 1509223934
}

\begin{abstract}
Mechatronics engineering courses at undergraduate and graduate levels, as well as vocational training courses are rapidly increasing across the world. Philosophy and structure of such courses divert from the classical single-discipline engineering programmes and induce a challenge for the higher education institutions. Different institutions in various countries are reacting differently to this challenge but, all aiming at educating mechatronics engineers. This paper reviews the mechatronics education at various centres in the world. It also analyses the structure and contents of a number of selected mechatronics programmes in various higher education institutions. Furthermore, it proposes a list of features that a sound mechatronics engineering programme should contain.
\end{abstract}

Keywords: mechatronics, engineering, education, curriculum

\section{Mechatronics Philosophy vs Traditional Engineering Thinking}

Most engineered products or processes have moving parts and require manipulation and control of their dynamic constructions to a required accuracy. This may involve a combination of the enabling technologies such as sensors, actuators, structural mechanics, electronics, microcontrollers, software and control engineering, neural networks, fuzzy logic and active materials. A key factor in the mechatronics philosophy is the integration of microelectronics, computing and control into mechanical systems, so as to obtain the best possible design solution and a product with a degree of intelligence and flexibility. Design of such products and processes, therefore, has to be the outcome of a multi-disciplinary activity rather than an interdisciplinary one and must address other factors such as appropriateness. In all cases it is of paramount importance that the adoption of a mechatronics design approach should have some added value. This may either be in terms of added functionality for the same price or a reduced price for similar functionality when compared with a product produced by a more conventional approach. Hence mechatronics philosophy challenges traditional engineering thinking and practices because the integrated approach in the selection of means to the contemplated functional ends must involve, by nature, a team activity and crossing the boundaries between conventional engineering disciplines.

Mechatronic design philosophies and concurrent practices for achieving the physical embodiment of those designs are seen as an appropriate response to the challenge. The adoption of such philosophies, beginning at conceptual design level, requires engineers with a new range of skills and attitudes, with a concomitant stimulus to the providers of training and education. The true mechatronics engineer of the future is the rare individual who is able to work across the boundaries of constituent disciplines to identify and use the right combination of technologies which will provide the optimum solution to the problem in hand. He/she should also be a good communicator who is able work in and lead a design team which may consist of specialist engineers as well as generalists. Universities and colleges are currently reacting to this challenge in their own different ways. 
This paper attempts to summarise how some higher education institutions in various countries are reacting to the challenge of educating mechatronics engineers of the future and tries to paint a picture of activities across the world. Although every effort is made to give a wide coverage of the mechatronics programmes, the author does not claim that the lists given here are fully comprehensive. He would be grateful to receive further information on new courses or other existing ones which are omitted here, as well as updates of the ones mentioned here.

\section{TrAining THE MECHATRONICS ENGINEER OF THE FUTURE}

Both in Europe and the USA the traditional engineering education system is oriented towards producing specialist engineers with narrow and deep specialisation. Although many engineering departments in the UK universities were conceived initially as departments of engineering, with only a very few notable exceptions they have developed into specialist departments, churning out specialist engineers. This is also true of the most USA and European universities. Even those which have maintained the broad ideals of general engineering promote final year specialisation. There is some evidence, in the UK at least, that the move towards specialist departments is recognised as divisive and there is a swing towards a return to the integrated faculty structure which is in line with a closer working relationship of the professional engineering institutions.

In recent decades, there has been a move in industry to return to more integrated production techniques and, with the development of microprocessors and microprocessor controlled systems and products, a need for integration in engineering design and education. The modern commercial climate is causing companies to rationalise their operations to adopt best practice or to go to the wall. Industry is now demanding engineers with both great depth and breadth. If generalism is taken too far then the engineers have covered a wide range of topics in insufficient depth to be of use. Thus the education and training of mechatronics engineers is not an easy task. In any case it is not sufficient to teach a wide range of topics and call the product a mechatronics engineer; the thorny problem of integration must be properly addressed.

A considerable number of higher education institutions in various countries are offering mechatronics education and naturally their response to the 'educating mechatronics engineer challenge' varies depending on their culture, system, and the availability of existing courses and resources. There is some evidence that many undergraduate degree programmes in mechatronics are simply a gluing together of mechanical and electronic components lacking a coherent integrative theme. This is obviously not ideal. On the other hand, some institutions are designing mechatronics degree programmes from scratch with integrating design projects running through the programme.

Mechatronics engineering courses at undergraduate and postgraduate levels as well as vocational training courses have been rapidly increasing in higher education institutions in Europe, particularly in the UK, USA, Australia and Pacific Rim. These developments have been reported in the proceedings of a number of international mechatronics conferences in recent years which included a special session or a selection of papers on mechatronics education and training. The 1994 Stanford University Workshop on Mechatronics Education [1] had many contributors, mainly from North American institutions. 1994 Budapest Mechatronics Conference [2], and 1995 Istanbul Mechatronics (ICRAM'95) Conference [3] included special sessions on Mechatronics education and training. 1994 Australia and 1995 Hong Kong M²VIP Conferences [4] also included papers on the subject. In particular, the special session of the ICRAM'95 Conference has brought together about a dozen papers on mechatronics education and training from eight different countries giving it a truly international flavour. Mechatronics Journal also dedicated a Special Issue on "Mechatronics Education in the USA" [5]. 


\section{JAPANESE APPROACH}

The Japanese university educational system tends to foster engineers with a trans-disciplinary approach. Japanese educationalists see the mechatronics engineer as a broader based mechanical engineer who has a good hands-on knowledge and ability in microprocessor hardware and software, electronics, actuators and control. The Japanese national university system aids the formation of mechatronics engineers with good R\&D skills of benefit to industry. Undergraduate programmes are four years in length with the entire final year spent full time on a laboratory based research project; the final year of the two year masters programmes is also spent on such a project. Postgraduate education in Japan is considered as both necessary and a good investment.

Most Japanese companies assume that design is learnt on the job, backed by in-house training. In addition to formal training the best way of creating engineers with general skills is to operate incompany education and job rotation schemes. The need for mechatronics engineers will depend on the company; some feel that generalist engineering training produces suitable engineers for mechatronics project teams, hence they rely upon generalist education and co-operation within the project team for the development of mechatronic products and processes. Others think that special programmes for mechatronics are necessary and feel that they can only be trained in house.

Many engineering departments in Japanese universities teach elements of mechatronics within their programmes. For example, Toyohashi University runs a regular ME course since 1983 in Mechatronics Engineering. Another example of commitment to mechatronics manifests itself in the change of name of the Department of 'Precision Engineering' to 'Mechatronics and Precision Engineering'.

\section{UNITED KINGDOM SCENE}

In recent years mechatronics gained an increasingly prominent place in the UK higher education scene. This is clearly visible from the rapidly increasing number of undergraduate degree programmes and MSc programmes offered by a number of higher education institutions.

A typical BEng (Bachelor of Engineering) degree in an English university is normally of three year duration, which is approximately equivalent of the sophomore, junior and senior years in a US university engineering degree programme, since students start their engineering degree at a higher level in the UK. Four-year MEng (Master of Engineering) programmes are gaining popularity and many institutions nowadays offer MEng as well as BEng degrees. At the undergraduate level, several course providers in the UK feel that a suitable mechatronics degree can be offered within the normal three year duration of a typical UK degree programme for a first degree. Opponents of this approach feel that it is not possible to give the required breadth and depth in three years and believe that a suitable mechatronics degree should have an extended study period. Others offer mechatronics education as a post graduate masters course only and concentrate on giving more breadth and appreciation to single discipline graduates.

\section{Undergraduate Courses}

Lancaster University established the first undergraduate degree course in mechatronics as a specialist option of their electronic and mechanical engineering courses. The University of Hull and Leeds University have followed soon after. Several other universities and colleges have since embraced the subject to the extent of offering mechatronics courses at BSc, BEng and MEng levels. These include King's College London, Sussex University, Staffordshire University, Manchester Metropolitan University, Middlesex University, De Montfort University, University 
of Abertay Dundee, Glamorgan University and Swansea Institute of Higher Education, offering courses at degree level.

Table 1. Mechatronics Undergraduate Courses in the U.K.

\begin{tabular}{|l|c|c|}
\hline University & BEng & MEng \\
\hline De Montfort Univ. & $\checkmark$ (BSc) & \\
\hline University of Abertay Dundee & $\checkmark$ (BSc) & \\
\hline Glamorgan University & $\checkmark$ & $\checkmark$ \\
\hline Glasgow Caledonian University & $\checkmark$ & \\
\hline University of Hull & $\checkmark$ & $\checkmark$ \\
\hline King's College London & $\checkmark$ & $\checkmark$ \\
\hline Lancaster University & $\checkmark$ & $\checkmark$ \\
\hline University of Leeds & $\checkmark$ & \\
\hline Manchester Metropolitan Univ. & $\checkmark$ & \\
\hline Middlesex University & $\checkmark$ & $\checkmark$ \\
\hline Staffordshire University & $\checkmark$ & \\
\hline Sussex University & $\checkmark$ & \\
\hline Swansea Institute of HE & & \\
\hline
\end{tabular}

The degree programmes offered by these universities are summarised in the Table 1 . It should be noted that whilst some institutions have designed mechatronics courses from scratch others have done little more than putting together modules from electrical and mechanical engineering departments to create a mechatronics programme or renaming existing 'electromechanical' or 'systems' engineering type programmes, paying scant attention to the fundamental issue of integration. Details of two undergraduate programmes from two British universities, namely University of Lancaster and University of Hull, are given in Tables 2 and 3.

Table 2: Mechatronics Course at the Lancaster University

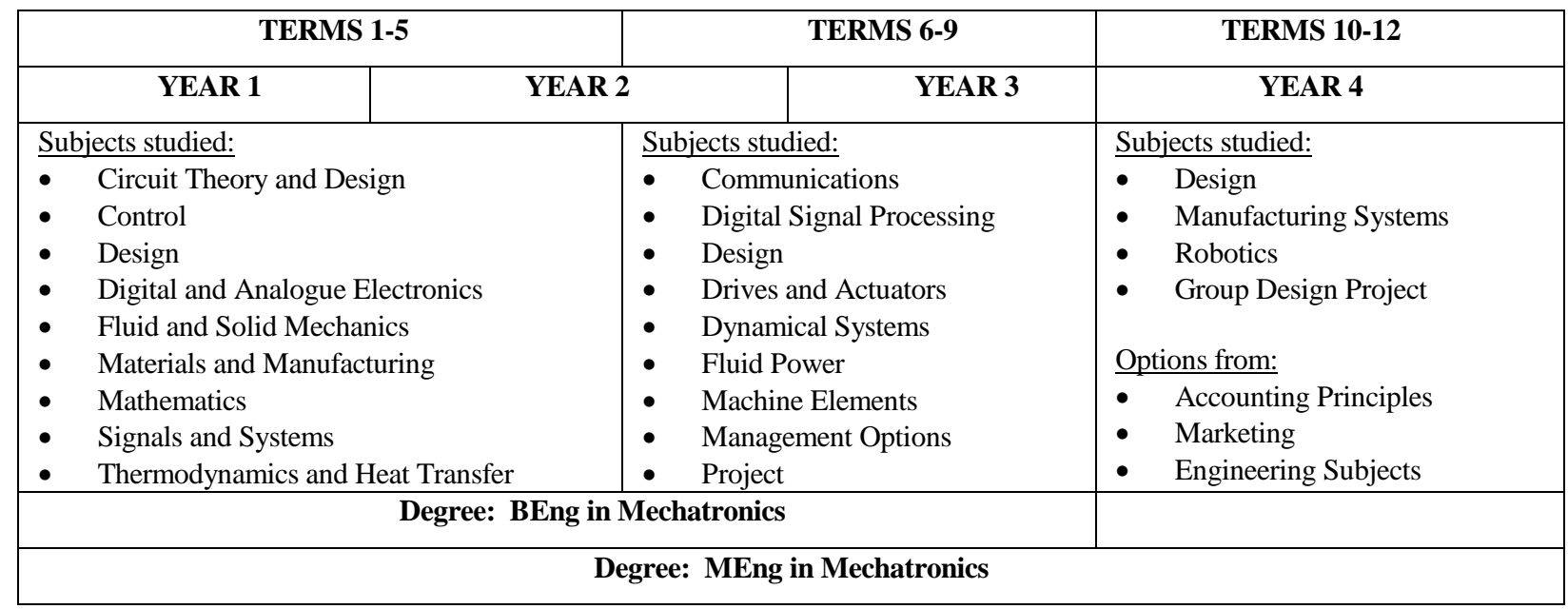

Numerous universities and colleges of higher education also offer technician level courses. Furthermore, the Open University also offers a course entitled 'Mechatronics: Designing Intelligent Machines'. 
Table 3: Mechatronics BEng Course at the University of Hull

\begin{tabular}{|c|c|c|c|}
\hline YEAR 1 & YEAR 2 & YEAR 3 & YEAR 4 \\
\hline $\begin{array}{ll}\text { Projects }(50 \%) \\
\text { Lecture Topics (50\%): } \\
\text { - } & \text { Principles of Design } \\
\text { - } & \text { Computer Systems } \\
& \text { and Programming } \\
\text { - } & \text { Materials } \\
\text { - } & \text { Mechanical Systems } \\
\text { - } & \text { Project Planning \& } \\
\text { - } & \text { Management } \\
\text { - } & \text { Clectronic Design } \\
\text { - } & \text { Drives and Sensors } \\
\text { - } & \text { Report Writing }\end{array}$ & \begin{tabular}{ll}
\multicolumn{2}{l}{ Projects $(50 \%)$} \\
Lecture Topics $(50 \%)$ : \\
- & Transducer Technology \\
- & Microprocessor Systems \\
- & Project Management \\
- & Control \\
- & Principles of \\
- & Manufacturing \\
- & Design for Manufacture \\
- & Business Finance
\end{tabular} & $\begin{array}{ll}\text { Lecture Topics: } \\
\text { - } & \text { Software Engineering } \\
\text { - } & \text { Manufacturing Systems } \\
& \text { Computer Aided } \\
\text { - } & \text { Engineering } \\
& \text { Industrial and Production } \\
\text { - } & \text { Management } \\
\text { - } & \text { Dutomatic Control } \\
\text { - } & \text { Logital Systems } \\
\text { - } & \text { Techniques in Design for } \\
& \text { Manufacture }\end{array}$ & \begin{tabular}{ll}
\multicolumn{1}{l}{ Individual Project } \\
Six topics to select from: \\
- & Automated Assembly \\
& Systems \\
- & Design Analysis \\
- & Flexible Manufacturing \\
& Systems \\
- & Industrial Control Systems \\
- & Knowledge-Based \\
& Engineering \\
- & Robotics Engineering \\
- & CAD \\
& Advanced Techniques in \\
& Control
\end{tabular} \\
\hline
\end{tabular}

\section{MSc Courses}

Lancaster University was one of the earliest involved whilst the MSc at Dundee is notable in that it involves co-operation between University of Dundee and University of Abertay. The course at De Montfort University has a considerable emphasis on a multi-national student body and European student exchange and emphasises the business environment. Loughborough University is one of the most advanced providers with a novel delivery suited to the attendance of part-time industrially based students. The course at the University of Hull follows a week-long-module pattern similar to the Loughborough course. King's College London and City University are the two new players in the scene of MSc courses. Table 4 gives a list of MSc courses offered in the UK and Table 5 provides details of a one-year MSc course entitled "Design of Mechatronic Products” offered by Loughborough University. This programme consists of taught lecture courses and a project which requires a written dissertation.

Table 4. Mechatronics MSc Courses in the U.K.

\begin{tabular}{|l|c|}
\hline University & MSc Programme \\
\hline City University & $\checkmark$ \\
\hline De Montfort University & $\checkmark$ \\
\hline University of Dundee & $\checkmark$ \\
\hline University of Hull & $\checkmark$ \\
\hline King's College London & $\checkmark$ \\
\hline Lancaster University & $\checkmark$ \\
\hline Loughborough University & $\checkmark$ \\
\hline
\end{tabular}

Table 5: One-year MSc Course at Loughborough University

\begin{tabular}{|c|}
\hline Taught and Examined Modules: \\
\hline Microprocessor Applications \\
Mechatronic Systems \\
Engineering Design Methodologies \\
Computer Aided Engineering \\
Engineering Design Process and Project Management \\
Engineering Design Management and Business Studies \\
\hline Project and Dissertation \\
\hline
\end{tabular}




\section{EURopean Programmes}

Scandinavian countries such as Sweden, Finland and Denmark have the longest tradition of mechatronics activities in Europe. The Royal Institute of Technology (KTH) of Sweden has been involved with mechatronics education since 1970s, mainly in the form of teaching 'design of embedded systems' in conjunction with the mechanical engineering courses. Technical University of Denmark teaches the mechatronics concept as an element of the engineering design process. Table 6 gives a list of European universities offering mechatronics courses.

Table 6. Mechatronics Education in Europe

\begin{tabular}{|l|l|c|c|c|}
\hline Country & University & $\begin{array}{c}\text { UG Degree } \\
\text { Programme }\end{array}$ & $\begin{array}{c}\text { Elements of } \\
\text { Mechatronics }\end{array}$ & $\begin{array}{c}\text { Masters } \\
\text { Programme }\end{array}$ \\
\hline Finland & Helsinki University of Technology & & $\checkmark$ & $\checkmark$ \\
Sweden & Royal Inst. of Technology, KTH & $\checkmark$ & $\checkmark$ \\
Denmark & Technical Univ. of Denmark, DTH & $\checkmark$ & $\checkmark$ \\
Austria & University of Linz, Austria & $\checkmark$ & & $\checkmark$ \\
Germany & Darmstadt Institute for Mechatronics & & & $\checkmark$ \\
Switzerland & ETH Zurich & & $\checkmark$ & $\checkmark$ \\
Belgium & Katholieke University of Leuven & & & $\checkmark$ \\
\hline
\end{tabular}

In Austria, Johannes Kepler University of Linz offer a five-year mechatronics degree programme. This course, based within the Institute for Mathematics, covers all fundamental elements of mechatronics as detailed in Table 7, but tends to be more theoretical than one expects from a mechatronics undergraduate programme. The course is organised in two parts, taking two and three years respectively and a diploma thesis. Katholieke University of Leuven has also been active in this field and offers a course in mechatronics.

Various other institutions in Germany, Switzerland, Netherlands, Belgium are also active in mechatronics. Among these we can mention Institutes of Mechatronics in universities of Darmstadt, Chemnitz and Duisburg, Mechatronics Laboratory at University of Paderborn, ETH Zurich and Twente University. The author is not aware of full degree programmes offered by these institutions but elements of mechatronics are taught within the classical degree programmes such as mechanical and electrical engineering

Table 7. Mechatronics Curriculum at University of Linz, Austria

(Numbers in brackets show weighting, 1 unit $=6$ hours/week approximately)

\begin{tabular}{|l|l|}
\hline \multicolumn{1}{|c|}{ Part One (Two years) } & \multicolumn{1}{c|}{ Part Two (Three years) } \\
\hline 1. Mathematics (3) & 1. Applied Mathematics (1) \\
\hline 2. Computer Science (2) & 2. Computer Science (1) \\
\hline 3. Engineering Mechanics (2) & 3. Engineering Mechanics (1) \\
\hline 4. Mechanical Engineering (3) & 4. Mechanical Engineering (1.5) \\
\hline 5. Electrical Engineering (4) & 5. Electrical Engineering (3) \\
\hline 6. Physics (1.5) & 6. Control and Automation (2) \\
\hline & 7. Bionics (0.5) \\
\hline & $\begin{array}{l}\text { Options (6): from the following list including a team work project } \\
\text { - Engineering Mechanics and Robotics }\end{array}$ \\
& $\begin{array}{l}\text { - Drive Technology } \\
\text { - Control and Automation }\end{array}$ \\
& $\begin{array}{l}\text { - Measurement Technology Automation in Process Engineering } \\
\text { - Microelectronics }\end{array}$ \\
\hline & $\begin{array}{l}\text { None-technical Options (2.5) } \\
\text { None technical subjects from any Austrian University, e.g.: Foreign } \\
\text { Languages, Economics, Business. Law,...) }\end{array}$ \\
\hline Diploma Thesis: On completion of the five academic years, students are required to complete a diploma thesis.
\end{tabular}




\section{DEVELOPMENTS IN USA UNIVERSITIES}

Each of the US universities which claims to teach mechatronics, mainly offers a course (module or unit) in microprocessor or micro-controller applications, usually at the senior year level. A list of these institutions can be found in Table 8. Some institutions offer modules in mechatronics product or system design, but no coherent total degree programme was offered in any US university. This is sometimes due to the structure and rules of the institution (e.g., in some cases to offer a degree programme it would be necessary to have a Department of Mechatronics). An exception to this is the integrated inter-departmental curriculum which is being developed jointly by the Mechanical and Electrical Engineering Departments of the Ohio State University. This pilot project is sponsored by a NSF-DUE curriculum development grant and also supported by the Ford Motor Company.

Table 8. Mechatronics Education in North America

\begin{tabular}{|c|c|c|}
\hline University & Module (Course) Title & Department \\
\hline Ohio State University, Columbus & $\begin{array}{l}\text { Design of Mechatronics Systems: An } \\
\text { Integrated Inter-Departmental Curriculum }\end{array}$ & $\begin{array}{l}\text { Mechanical Engineering and } \\
\text { Electrical Engineering }\end{array}$ \\
\hline San Jose State University, California & $\begin{array}{l}\text { Mechatronics Systems Engineering: a new } \\
\text { curriculum stem (not a new degree } \\
\text { programme) }\end{array}$ & $\begin{array}{l}\text { Mechanical and Aerospace } \\
\text { Engineering. }\end{array}$ \\
\hline $\begin{array}{l}\text { Stanford University, Palo Alto, } \\
\text { California }\end{array}$ & Smart Product Design & Mechanical Engineering \\
\hline $\begin{array}{l}\text { Rensselaer Polytechnic Institute, Troy, } \\
\text { NY }\end{array}$ & Mechatronics System Design & Mechanical Engineering \\
\hline Massachusetts Institute of Technology & Designing Smart Machines & Mechanical Engineering \\
\hline $\begin{array}{l}\text { Georgia Institute of Technology, } \\
\text { Atlanta }\end{array}$ & Microprocessors System Design & Mechanical Engineering \\
\hline University of California at Berkeley & $\begin{array}{l}\text { Microprocessor Based Design of } \\
\text { Mechanical Systems }\end{array}$ & Mechanical Engineering \\
\hline University of Tulsa, Tulsa, OK & Mechatronics & Mechanical Engineering \\
\hline University of South Carolina, Columbia & Fundamentals of Microprocessors & Mechanical Engineering \\
\hline $\begin{array}{l}\text { Rose-Hulman Institute of Techn., Terre } \\
\text { Haute, Indiana }\end{array}$ & Microprocessor Technology & Mechanical Engineering \\
\hline $\begin{array}{l}\text { Colorado State University, Fort } \\
\text { Colloins }\end{array}$ & Mechatronics and Measurement Systems & Mechanical Engineering \\
\hline $\begin{array}{l}\text { Purdue University, West Lafayette, } \\
\text { Indiana }\end{array}$ & $\begin{array}{l}\text { Microprocessors in Electromechanical } \\
\text { Systems }\end{array}$ & Mechanical Engineering \\
\hline Iowa State University, Ames & Microprocessor Based Systems Design & $\begin{array}{l}\text { Electrical Engineering and } \\
\text { Computer Engineering }\end{array}$ \\
\hline Univ. of Washington, Seattle & Design of Consumer Electronics & Electrical Engineering \\
\hline University of Delaware, Wilmington & Mechatronics Design & Computer and Info. Sci. \\
\hline $\begin{array}{l}\text { Concordia University, Montreal } \\
\text { (Canada) }\end{array}$ & Microprocessors and Applications & Mechanical Engineering \\
\hline
\end{tabular}

The examples of 'Mechatronic System Design' or 'Smart Product Design' or 'Designing Smart Machines' can be seen at the Rensselaer Polytechnic Institute, Stanford University and Massachusetts Institute of Technology. These courses are usually offered to senior or masters level students and require mechatronics products and systems projects to be designed, built and tested and sometimes contested between groups. Currently, the National Science Foundation's Undergraduate Education Division is sponsoring a project entitled 'Preparing the Leaders for Mechatronics Education' to be undertaken by Cal Poly's Industrial and Manufacturing Engineering Department. This is an indication of the emphasis placed on further developing mechatronics education in the USA. It will not be too long before we see a full degree programme in mechatronics engineering in a USA university. A further funding by National Science Foundation was awarded to San Jose State University, California to develop a new 
curriculum stem (not a new degree programme) in Mechatronics Systems Engineering in the Department of Mechanical and Aerospace Engineering. This will involve developing five new courses (modules) and a new mechatronics engineering laboratory, also with the aid of donated equipment by a leading computer company. The undergraduate courses to be developed are as follows:

- Fundamentals of Mechatronics engineering,

- Electromechanical system and microprocessor applications,

- Design for manufacturability in electronics and computer equipment,

- Introduction to micro-manufacturing, and

- Control of Manufacturing Processes.

The mechatronics Engineering Laboratory was developed to support the instruction of Mechatronics Systems Engineering course and to enable students to gain significant hands-on laboratory experiences in mechatronics.

\section{Australia AND FAr EAST}

A number of universities in Australia offer undergraduate degree programmes in Mechatronics (Table 9). The University of Sydney initiated a programme in 1990 which already graduated their first intake. This course is based on mechanical engineering which also attracts the support of electrical engineering. First two years of the course is mostly common to both mechanical and mechatronics engineering students. with the difference that mechatronics engineering students take further electronics and carry out an introductory mechatronics design project. Room was created for these subjects by reducing the content of thermofluids on the course. The overlap between the mechatronics and mechanical students are reduced to $50 \%$ in the third year. Mechatronics students take additional subjects like electrical machines and drives, industrial electronics, and digital systems. In addition students take a full-year laboratory course consisting of short, structured and long, open-ended practical work. In the fourth and final year the emphasis is on the professional development. There are two compulsory elements: professional communications and research or development project, which constitutes a significant part of the final assessment. The balance is made up with elective subjects most of which are project based.

Table 9. Mechatronics Education in the Rest of the World

\begin{tabular}{|l|l|c|}
\hline Country & University & UG Degree Programme \\
\hline Australia & University of Sydney, NSW & $\checkmark$ \\
& James Cook Univ. of North Queensland & $\checkmark$ \\
& University of Southern Queensland & $\checkmark$ \\
& University of New South Wales & $\checkmark$ \\
\hline Hong Kong & City University of Hong Kong & $\checkmark$ \\
\hline S. Korea & ChungNam National University & $\checkmark$ \\
\hline
\end{tabular}

There are also a number of newer players in the game mechatronics education, namely James Cook University, University of South Queensland and University of New South Wales. James Cook University developed its mechatronics course in collaboration with the Royal Institute of Technology of Sweden. USQ and UNSW have based their courses in their mechanical engineering departments with contributions from the electrical engineering and computer science sections within the last two years of the four year degree programmes.

Hong Kong City University is offering a mechatronics degree programme since 1992, developed jointly by the departments of electrical engineering and manufacturing engineering. The important features of this course are: induction of student centred activity in every major theme, a 
major design project concentrating on either process or product mechatronics and development of suitable laboratory facilities to cater for the mechatronics activity. Students are required to attend, in summer terms, simulated practical training modules which take place at the university laboratories. The course structure is given in Table 10 .

Mechatronics is also establishing itself as major discipline in Korean institutions. A typical example is ChungNam National University which is heavily investing in the development of mechatronics activities.

Table 10. Mechatronics Engineering BEng degree course at City University of Hong Kong

\begin{tabular}{|c|c|c|}
\hline Year 1 & Year 2 & Year 3 \\
\hline $\begin{array}{l}\text { Semester A: } \\
\text { Basic Electronic Engineering I } \\
\text { Software Data Organisation } \\
\text { Engineering Materials } \\
\text { Manufacturing and Society } \\
\text { Engineering Analysis and Design I } \\
\text { Engineering Mathematics I } \\
\text { Technical Communications for } \\
\text { Engineers I }\end{array}$ & $\begin{array}{l}\text { Semester A: } \\
\text { Instrumentation Design I } \\
\text { Microprocessor Interfacing and Comp. } \\
\text { Org. } \\
\text { Control Principles } \\
\text { Design for Manufacture I } \\
\text { Mechanical Design }\end{array}$ & $\begin{array}{l}\text { Semester A: } \\
\text { Power Electronics \& Drive Systems } \\
\text { Motion Control Design } \\
\text { Design Project II } \\
\text { Design Management }\end{array}$ \\
\hline $\begin{array}{l}\text { Semester B: } \\
\text { Basic Electronic Engineering II } \\
\text { Engineering Materials (Cont.) } \\
\text { Introduction to Manufacturing } \\
\text { Processes } \\
\text { Heat and Fluid Flow } \\
\text { Eng. Analysis and Design II } \\
\text { Technical Communications for } \\
\text { Engineers II }\end{array}$ & $\begin{array}{l}\text { Semester B: } \\
\text { Instrumentation Design II } \\
\text { Embedded Systems Software } \\
\text { Engineering } \\
\text { Manufacturing Communications \& } \\
\text { Databases } \\
\text { Design for Manufacture II } \\
\text { Design Project I } \\
\text { Engineering Mathematics II }\end{array}$ & $\begin{array}{l}\text { Semester B: } \\
\text { Design Project II (Cont.) } \\
\text { Product Design Stream: } \\
\text { Computer Aided Engineering I } \\
\text { Computer Aided Engineering II } \\
\text { Mechatronic Product Design } \\
\text { Process Mechatronics Stream: } \\
\text { Product Quality and Reliability } \\
\text { Flexible Manufacturing Systems } \\
\text { Mechatronic Production Equipment }\end{array}$ \\
\hline
\end{tabular}

\section{CONCLUDING REMARKS}

The fierce international competition in design and development of mechatronics products and systems demands significant attention to be given to mechatronics education and raising the awareness of mechatronics approach to design of products and processes. The initial urgent task of the engineering educationalist should be to make engineers at all levels aware of the mechatronics concepts applied to product design and its significance to industry. The importance of mechatronics design must be stressed at all levels in the teaching and training of engineering, particularly in mechanical and electronic engineering. It is perhaps not possible nor desirable to convert every mechanical and electronic engineer into a mechatronics engineer, but the point is that traditional engineers must learn to appreciate the other specialist disciplines and hence to communicate with them at the product design stage. Hence, mechatronics engineers must have broader backgrounds but with specialist knowledge of a discipline and abilities to operate in a multi-disciplinary project team.

The engineering education and training systems for mechatronics engineering may have to move or return to generalist courses at undergraduate level not only to provide broader background than conventional undergraduate programmes, covering all the constituent disciplines of mechatronics but also to accommodate depth at least in one of the major disciplines. Expanding breadth but preserving depth can only be achieved by increasing the number of years for mechatronics engineering education. 
Integration of constituent disciplines of mechatronics through structured and open ended practical work, individual and group projects will have to be an essential element of a mechatronics degree programme. Without this, mechatronics programmes would go no further than being a typical 'electromechanical' degree. Integration can be achieved by teaching students from the first year the mechatronic design philosophy and supporting this with design projects running at every year of the programme. These projects can vary from artefact analysis (reverse engineering) and conceptual designs at earlier years to design and make projects in later years. It is essential that students develop 'team work' approach to design and development projects and become effective communicators.

It is essential that industry also plays its part in the formation of the mechatronics engineers of the future. Indeed it is important that industry adopts a leading role by participating in the development of courses at universities, providing real-world design projects for students to facilitate the integration of the elements of mechatronics degree programmes, and offering industrial placements (internship) to students. Moreover, it is also important that industry accepts that in-house training is worthwhile for engineers employed and further specialisation can also be gained at university based graduate level training.

It is not feasible to prescribe a detailed course content for a typical mechatronics course since there will be significant variations in the curricula stemming from the national and regional culture, teaching practices, and resources available. Nevertheless, the author suggests that a sound mechatronics engineering programme should have the following features:

- The programme duration should be longer than a typical single disciple engineering programme to enable the coverage of both breadth and width of the essential mechanical, electrical/electronic and computing subjects.

- An integrating thread of practical analysis and synthesis projects should run at every level throughout the programme. A combination, without integration, of suitable mechanical and electronics engineering and computing courses would not be suitable.

- Mechatronics philosophy should be continuously taught throughout the programme.

- There should be structured and open ended practical laboratory work to develop the necessary practical skills.

- Effective communication skills and ability to work in teams are essential skills and should be developed to a professional level.

- Input from industry in the form of real life design and development projects and supervision of such projects by experienced engineers is highly desirable.

- Several student placements in industry (or internship) lasting one summer or one semester each, or better still an integrated sandwich (or co-op) type industrial training programme to provide the students with an opportunity to work in engineering project teams in industry would also be highly desirable in order to give them valuable hands-on engineering experience. 


\section{REFERENCES:}

1. Proceedings of the Workshop on Mechatronics Education, Stanford University, July 21-22, 1994, 116pp.

2. "Topic 7: Mechatronics in Education” in: The Basis of New Industrial Development (Eds. Acar M, Makra J and Penney E), Computational Mechanics Publications, 1994, Southampton, pp763-823.

3. "Special Session on Mechatronics Engineering Education and Training” in: Recent Advances in Mechatronics, Vol. I, Proceedings of International Conference on Recent Advances in Mechatronics (Eds. Kaynak O, Ozkan M, Bekiroglu N and Tunay I), August 14-16, 1995, Istanbul, pp238-307.

4. "Mechatronics Education in the USA - Special Issue”, Mechatronics, Vol. 5, No. 7, 1995, pp721-853.

5. Proceedings of Mechatronics and Machine Vision in Practice Conference, September 13-15, 1994, Toowoomba, Australia

\section{Dr Memis Acar}

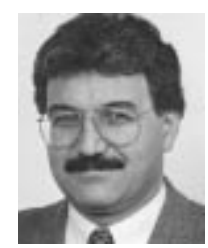

Memis Acar gained BS degree in Mechanical Engineering from Middle East Technical University (METU), Ankara, Turkey, MSc degree in Textile Technology from University of Manchester Institute of Science and Technology (UMIST) and $\mathrm{PhD}$ degree from Loughborough University of Technology. He is currently Senior Lecturer in Mechanical Engineering at Loughborough University.

He is Member of ASME, Fellow of Institution of Mechanical Engineers (FIMechE) and Fellow of the Textile Institute (FTI). He is acting as the Vice Chair and the Chair Elect of the UK Mechatronics Forum, functioning under the auspices of the IMechE and IEE. He is also CoEditor-in-Chief of the International Journal of Intelligent Mechatronics (IJIM). 